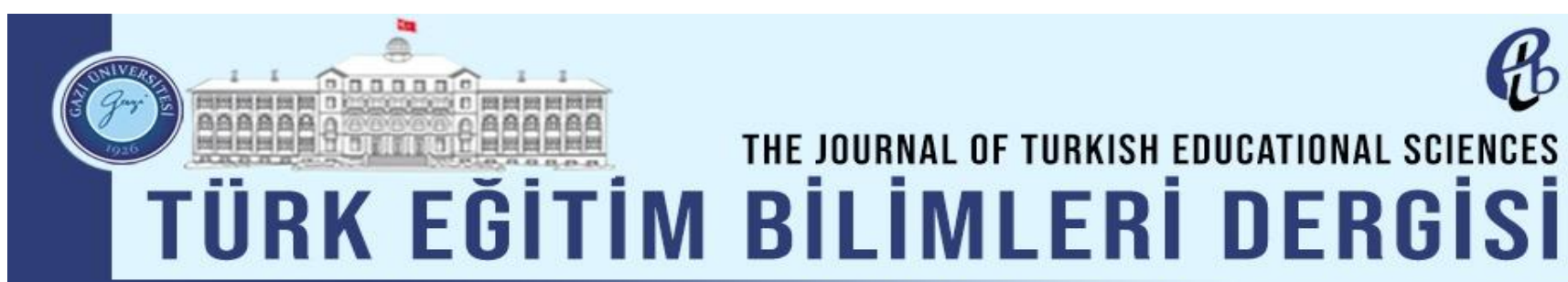

\title{
Okullarda Örgütsel Demokrasi Ölçeği'nin Geliştirilmesi: Geçerlik ve Güvenirlik Çalışması
}

\section{Developing Organizational Democracy Scale in Schools: Validity and Reliability Study}

\begin{tabular}{|c|c|}
\hline \multicolumn{2}{|r|}{ Süheyla Bozkurt Balcı } \\
\hline Yazar Bilgileri & ÖZ \\
\hline $\begin{array}{l}\text { Süheyla Bozkurt Balcı } \\
\text { Dr. Öğr. Üyesi, Çankırı } \\
\text { Karatekin Üniversitesi, Eğitim } \\
\text { Bilimleri, } \\
\text { sbozkurtmagici@hotmail.tr }\end{array}$ & 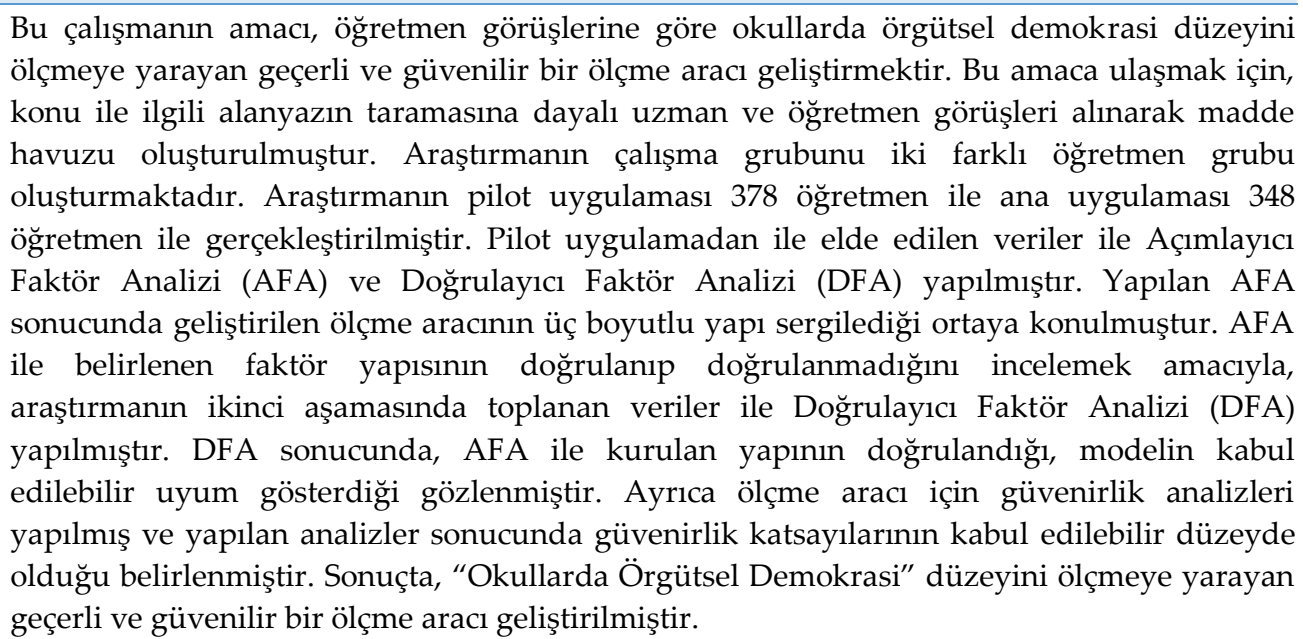 \\
\hline
\end{tabular}

\begin{tabular}{|c|c|}
\hline Makale Bilgileri & ABSTRACT \\
\hline Anahtar Kelimeler & This study aims to develop a valid and reliable measuring tool serving to measure \\
\hline Eşitlik ve Adalet & organizational democracy level in schools according to views of teachers. An item pool was \\
\hline Hesapverebilirlik & created by taking the opinions of experts based on the literature review to achieve this goal. \\
\hline Katılim & Two different teacher groups constitute the working group of the study. The pilot practice of \\
\hline Örgütsel Demokrasi & $\begin{array}{l}\text { the research was carried out with } 378 \text { teachers, and the primary practice with } 348 \text {. } \\
\text { Exploratory Factor Analysis (EFA) was performed with the data obtained from the pilot }\end{array}$ \\
\hline Keywords & practice. Confirmatory Factor Analysis (CFA) was performed with the data collected in the \\
\hline Equality and Justice & second phase of the research to analyze whether the factor structure determined with EFA \\
\hline Accountability & was verified. As a result of CFA, the structure established with EFA was verified, and the \\
\hline Participation & model has been observed to have an acceptable fit. Besides, security analysis was made for \\
\hline Organizational Democracy & $\begin{array}{l}\text { the measurement tool, and as a result of the analyses, the reliability coefficient was } \\
\text { determined to be acceptable. In conclusion, a valid and reliable measurement tool has been }\end{array}$ \\
\hline Makale Geçmişi & developed to measure the level of "Organizational Democracy in Schools". \\
\hline
\end{tabular}

Geliş: 22.05.2021

Düzeltme: 06.07.2021

Kabul: 03.12.2021 


\section{Giriş}

Siyasal bir yönetim paradigması olarak ortaya çıkan demokrasi kavramının tanımı ve demokrasinin göstergelerinin neler olabileceği, insanların topluluk hâlinde yaşadığı tüm toplumlarda felsefenin, sosyal ve yönetim bilimlerinin konu alanına girmiştir. Demokrasi, Yunanca kökenli "demos" (halk) ve "kratos" (iktidar) kelimelerinin bir araya gelmesi ile "halkın halk tarafından yönetilmesi" "halkın egemenliğine dayanan yönetim biçimi" olarak tanımlanmıştır (Duverger, 1993; Ejder, 1996; Gözübüyük, 2003; Heywood, 2007). Temelinde eşitlik, katılım, adalet ve halkın egemenliği gibi kavramları barındıran demokrasi kavramı, "halkın halk tarafından yönetilmesinin" tam olarak mümkün olamayacağı düşüncesinden yola çıkılarak zaman zaman da eleştirilmiştir (Duverger, 1993; Rousseau, 2012).

Örgütlerde demokrasi kavramı, endüstri devriminden sonra fabrikalaşmayla birlikte, kötü koşullarda çalışan işçilerin haklarının korunması amacıyla ortaya çıkan sendikalar aracılığıyla "endüstriyel demokrasi" kavramı ile tartışılmaya başlanmıştır. Kavramın ortaya çıkış noktası önceleri çalışma koşullarının iyileştirilmesi, ücretlerin artırılması, işçilerin sendikal haklarının korunması iken zaman içerisinde örgüt yönetimine katılma, birlikte yönetim, özyönetim, işgören katılımı, katılımcı yönetim gibi kavramlarla genişletilmiştir (Cheney, 1995; McGregor, 2005; Müller-Jentsch, 1995).

Örgütsel demokrasi kavramı farklı şekillerde tanımlanmıştır. Örgütsel demokrasi örgütü ilgilendiren her türlü kararın işgören katılımı ile alındığı, hatta örgütlerde çalışan işgörenlerin kendilerinin örgütü yönettikleri yönetim biçimi olarak ifade edilmektedir (Smith, 1976). Butcher ve Clarke'a (2002) göre, örgütsel demokrasi, örgütlerde yöneticilerin yetki ve sorumluluk devri ile çalışanların karar alma sürecine katılmasını sağlamak ve yöneticilerin çalışanlara liderlik ederek kendi kendilerini örgütleyen birimler yaratmasına olanak vermektir. Harrison ve Freeman (2004) ise örgütsel demokrasiyi bir taraftan demokratik liderlik biçiminin yönetim eylemlerine yansıması diğer taraftan çalışma şartlarının düzenlenmesinden örgüt içindeki her türlü kararın işgören katılımı ile alınması ve nihayetinde örgütlerin işgörenler tarafından örgütlenmesine kadar her türlü eylemi kapsayan ve bu eylemlerin sonuçlarının birlikte denetlenmesini sağlayan yönetim biçim olarak tanımlamışlardır. Örgütsel demokrasi, kararlarda sadece yöneticilerin ve/veya hissedarların değil, örgüt içerisinde bulunan herkesin düşüncelerinin ortak bir fikir birliği sağlanarak alındığı örgütsel bir yönetim tarzıdır. Örgütsel demokraside önemli olan, örgüt içerisinde çalışanların karara katılımını teşvik edebilmektir (Witteloostuijn ve Jong, 2007). Dolayısıyla örgütsel demokrasinin sadece demokratik karar alma süreci ile değil, aynı zamanda örgütün içerisinde tüm yapı ve süreçlerin demokratik kurallara göre işlediği örgüt kültürü ile ilgili olduğu söylenebilir. Ticari mal üreten örgütlerde örgütsel demokrasiden söz edebilmek için üç koşuldan söz edilmektedir: Örgütün hissedar ve çalışanları arasında kâr payının paylaşılması; örgütü ilgilendiren her türlü kararın çalışanlar ve hissedarlar ile ortaklaşa alınması ve 
örgütteki yapı ve işleyişi destekleyen yasal çerçevenin oluşturulması ile demokrasi kültürünün örgüte nüfuz etmesinin sağlanması (Witteloostuijn ve Jong, 2007). Ancak kamu yönetiminde örgütsel demokrasi, siyasi ve ticari mal üreten örgütlerden farklı ön koşullar gerektirmektedir. Örgütsel demokrasi ile ilgili tanımların ortak noktası dikkate alınarak, örgütsel demokrasinin, örgütlerin varoluş nedenlerini yerine getirirken, örgütsel yapının kurulmasından görev ve sorumlulukların paylaşımına kadar kolektif düşünce biçiminin bireysel özgürlüklere saygı duyarak eşitliğe dayanan bir değerler sistemi yaratması ile oluşan yönetim biçimi olduğu söylenebilir.

Örgütsel demokrasi kavramı, siyasal demokrasi kavramından farklı niteliklere sahiptir. Siyasal demokrasilerde yönetilenler seçim yoluyla yönetenleri seçerken, örgütsel bağlamda çalışanların kendilerini yönetecek kişileri seçme hakkı yoktur. Siyasal demokrasilerde katılım vatandaşlara yasal olarak verilirken, örgütsel demokrasilerde katılım yönetimin inisiyatifine bağlı olarak değişebilir. Aynı şekilde siyasal demokrasilerde, devlet bilgiye serbestçe sahip olma ve paylaşma hakkına sahip iken, örgütsel bağlamda bilginin sahiplik ve paylaşım derecesi yönetimce kontrol edilir. Son olarak siyasal demokrasilerde yönetenler yönetilenlerin çıkarlarını ve kararlarını temsil edilebilmesi şartıyla yasallığı sağlar; örgütsel demokraside ise ekonomik değer üretmek ön plandadır (Kerr, 2004). Bu nedenle yönetim bilimi açısından siyasal demokrasinin tüm kurallarının örgütsel bağlama taşınması çok mümkün görünmemektedir. Ancak yönetim biliminin evrimsel sürecine bakıldığında, demokrasinin bazı kural ve ilkelerin modern yönetim anlayışına yansıdığı görülmektedir. 1960'lı yıllarda temeli geleneksel ve otoriter yönetim ve kontrol modeli olan McGregor'un öne sürdüğü $X$ teorisi (Davis, 1967) yönetim anlayışında yaygın olarak kullanılırken; günümüz modern yönetim anlayışında; örgütlerin amaçlarının, çalışanların sorumluluklarının ve ulaşacakları sonuçların birlikte belirlendiği amaçlara göre yönetim ya da çalışanların ekip çalışması yoluyla tüm kararlara katılım haklarını artırmaya yönelik personel güçlendirme yaklaşımı (Koçel, 2003) gibi yaklaşımlar daha çok kullanılmaya başlanmıştır.

Küreselleşme (Porta, 2005), İnternet ve bilişim teknolojilerindeki gelişmeler (Weare, 2002), 21. yy. dünya ekonomisindeki değişimler (Gomułka, 2017), X ve Y neslinden olanların örgütlerinden farklı iş beklentileri (Balcı ve Bozkurt, 2013) gerek ticari mal üreten örgütlerde gerekse kamu hizmeti sunan örgütlerde gücün yeniden dağılımını gerektiren yeni iş modellerinin ortaya çıkmasına neden olmuştur. Ortaya çıkan yeni iş modellerinde, örgütlenme sürecinde hiyerarşik yapılanmayı azaltma, serbest çalışma ilişkilerine yönelim, karar almada gücü ve sorumluluğu devretme ve doğru bir hesapverebilirlik sistemi kurma gibi demokratik değerlerin ve uygulamaların ortaya çıktı̆̆ görülmektedir (Diener, 2011).

Bir örgütte örgütsel demokrasiden söz edebilmek için bazı demokratik değer ve uygulamaların bulunması gerekir: Katılım; çalışanların tüm karar süreçlerine doğrudan ya da 
temsilcileri aracılı̆̆ ile katılmasıdır (Weber, Unterrainer ve Schmid, 2009). Katılım, örgütsel yapının içerisinde güç ve sorumluluğun göçerilmesi yoluyla kendi kendine düşünebilme, yargıda bulunabilme, seçim yapabilme ve eylemde bulunma süreçlerinin işe koşularak kendi kendini yöneten birimler oluşturmayı hedeflemektedir (Clarke ve Butcher, 2006). Eleştiri, örgütsel yapı ve süreçlerin çalışanlar tarafından olumlu veya olumsuz şekilde değerlendirilmesidir. Çalışanların örgütsel faaliyetleri, politika ve prosedürleri eleştirirken herhangi bir yaptırımla karşılaşmayacakları ile ilgili olarak güvenceye sahip olmaları gerekmektedir. Aynı zamanda eleştiri ve tartışma kültürünün örgütte demokratik bir teamül olarak yerleşmesi gerekir (Forcadell, 2005). Hesapverebilirlik, bir örgütte alınan her türlü kararın, yürütülen her faaliyetin (yönetsel ve finansal) sonuçları hakkında bilgilendirme hakkına sahip olmayı ve karar vericilerin hesap vermesini vurgulayan en temel demokratik ilkelerden biridir (Messner, 2009). Hesapverebilirlik aynı zamanda kamu kuruluşlarında ve işyerlerinde yürütülen politika ve faaliyetlerin çıktılarının sorgulanabilmesini zorunlu kılar (Bowles ve Gintis, 1993). Demokrasi, bireylere hak vererek ve güç dağılımını sağlayarak hesap talep etmeyi meşrulaştırır (Warren, 2014). Şeffaflık, çok temel demokratik değerlerden bir diğeridir. Şeffaflık bir örgütün içerisinde alınan kararların, çalışanlara doğru, eksiksiz, anlaşılabilir, yorumlanabilir ve kolay ulaşımının sağlanmasıdır. Böylece örgütler karşı karşıya kalabilecekleri olası riskleri paydaşları ve çalışanları ile paylaşabilirler (Hollyer, Rosendorff ve Vreeland, 2011). Eşittlik, bir örgütte ödül ve cezaların dil, din, cinsiyet, ideolojik görüş farklılığına bakılmaksızın adilane bir şekilde dağıtılması ile ilgili bir demokratik değerdir. Demokratik örgütlerde eşitlik ilkesi, mutlak eşitlikten ziyade, ödül ve cezaların dağıtımında koşulları eşit olanları gözeterek adil bir eşitlik anlayışını savunur (Colton, Edenfield ve Holmes, 2019). Adalet, bir örgütte çalışanların gelirlerinin adil bir şekilde dağıtılmasının yanı sıra, yönetimin izlediği strateji ve politikaların da adil bir şekilde dağıtılması ile ilgili bir kavramdır (Cropanzano ve Molina, 2015).

Kamu hizmeti üreten eğitim örgütlerinde de yukarıda zikredilen demokrasi ilkelerinden söz etmek mümkündür. Eğitim hizmeti üreten ve eğitim sisteminin yapı taşı olan okulların temel amaçlarından biri özgür ve eleştirel düşünebilen, insan haklarına saygılı demokratik değerlere sahip bireyler yetiştirmektir (Dewey, 2010). Bu açıdan düşünüldüğünde okulun demokratik bilgi ve anlayış oluşturma sürecine katkıda bulunmak gibi bir işlevi de vardır. Bu nedenle okullar, eşitlik ilkesiyle şekillenen bireylerin bireysel tercihler yapma, kendi yaşamına ilişkin projelerini gerçekleştirme konusundaki girişimlerini destekleyen ve öğrencilerin ilgi ve tercihlerini seçebildikleri “demokratik eğitim" anlayışını benimserler (O'Brien, 2005). "Demokratik eğitim" ile okullarda "örgütsel demokrasi" birbirinden faklı kavramlardır. "Demokratik eğitim”, özgürlük temelli bir anlayış çerçevesinde, toplumdaki çeşitlilikleri gözeterek, bireyler ile toplum arasında uyumlaştırma sağlama sürecidir (Morrison, 2008; Perry, 2009). Okullarda "örgütsel demokrasi” ise okulu ilgilendiren her 
türlü kararın okulda çalışanların katılımı ile alındığı, aynı zamanda örgütsel yapı ve süreçlerin demokrasi ilkeleri (katılım, eleştiri, hesapverebilirlik, şeffaflık, adalet ve eşitlik) ile desenlendiği bir yönetim biçimidir (Levin, 1981). Dolayısıyla "örgütsel demokrasi" bir yönetim biçimi olma özelliği ile “demokratik eğitim"den ayrılır.

Kavram olarak örgütsel demokrasi, örgütün tam olarak özerk olmasını gerektirir. Eğitim örgütlerinin âdem-i merkeziyetçi yapısı (Baş, 2017), okulların kendilerine ait bütçelerinin olmaması (Hoşgörür ve Arslan, 2014) okulda çalışacak öğretmenin ve yöneticinin çalışanlar tarafından seçilemiyor olması (Koçak ve Kavak, 2014) gibi nedenlerden ötürü eğitim örgütlerinde tam olarak örgütsel demokrasiden bahsetmek mümkün değildir. Ancak günümüz çağdaş devlet anlayışı, kamu kaynaklarının daha etkin ve rasyonel kullanımı için yöneticilere inisiyatif tanımış, örgütsel kararları yüksek bir otoriteyle veya otorite olmaksızın aldığı ancak önerilerini onay için bu otoriteye sunmak zorunda olduğu sınırlı bir özerklik vermiştir (Eurydice, 2014). Bu bağlamda yöneticilere kaynak tahsisatı yaratma ve kullanma bağlamında serbestlik tanıyan 5018 sayılı Kamu Mali Yönetimi ve Kontrol Kanunu kamu yöneticilerine birtakım haklar tanımıştır. Bu kanunla, yetkili mercilerce yapılacak denetimlerle okula aktarılan kaynakların stratejik önceliklere göre dağıtmak, bu kaynakların etkin kullanılıp kullanılmadığını izlemek ve bunun üzerine kurulu bir hesap verme sorumluluğu geliştirmek suretiyle okul yönetimine yetki verilmiştir (Özdemir ve Bozkurt, 2015). Bu açıdan düşünüldüğünde okulda alınacak stratejik kararlara eğitim paydaşlarının katılımı, okul yöneticilerinin hesap verme zorunluğunun bulunması, okulda her türlü iş ve işlemlerin şeffaflık ve açıklık ilkesi ile yürütülmesi gibi örgütsel demokrasinin pek çok ilkesinin okul örgütünde uygulanabilir olduğu görülmektedir. Dolayısıyla her ne kadar örgütsel demokrasi kavramının tam olarak özerk olan örgütler için uygun olduğu düşünülse de okul örgütleri de için de uygun olduğu söylenebilir.

Gerek siyasal demokrasinin gerek örgütsel demokrasinin göstergelerine ilişkin çalışmalar yapılmış olmasına rağmen bu iki kavramı etkileyen farklı değişkenler olması nedeniyle her iki kavramın nasıl ölçülebileceğine ilişkin bir görüş birliği sağlanmış değildir. Geçkil ve Tikici (2015) ticari mal üreten örgütlerde çalışanların örgütsel demokrasi algılarını kendi ifadeleriyle değerlendirmek üzere örgütsel demokrasi ölçeği geliştirmiştir. Ancak okullarda örgütsel demokrasinin genel görünümüne ilişkin herhangi bir çalışmaya rastlanamamıştır. Diğer taraftan alanyazında örgütsel demokrasi kavramının örgütsel bağlllık, örgütsel vatandaşlık, verimlilik, örgütsel adalet, örgüt kültürü ve örgüt iklimi gibi farklı değişkenlerle de ilişkileri olduğu yönünde bulgulara rastlanmıştır (Ahmend, Adeel, Ali ve Rehmann, 2019; Forcadell, 2005; Geçkil ve Tikici, 2016; Unterrainer, Palgi, Weber, Iwonowa ve Oesterreich, 2011; Verdorfer, Weber, Unterrainer ve Seyr, 2013; Yazdani, 2010). Okullar özelinde örgütsel demokrasi kavramının ilişkili olduğu diğer değişkenler üzerindeki etkilerinin araştırılabilmesi için de okullarda örgütsel demokrasinin genel görünümünün nasıl olduğunu ortaya 
koyan bir ölçek geliştirilmeye gereksinim duyulmuştur. Bu nedenle bu çalışmanın amacı okulda çalışan öğretmen algılarına göre geçerli ve güvenilir bir Örgütsel Demokrasi Ölçeği geliştirmektir.

\section{Yöntem}

$\mathrm{Bu}$ bölümde araştırmanın deseni, çalışma grubu, veri toplama aracının geliştirilmesi ve verilerin nasıl analiz edildiği ayrıntılı bir şekilde açıklanmıştır.

\section{Araştırmanın Deseni}

Okullarda örgütsel demokrasi düzeyini ölçmek için geçerli ve güvenilir bir ölçme aracı geliştirmeye odaklanan bu çalışma, temel araştırmalardan keşfedici araştırma yöntemi ile yürütülmüştür. Salt bilgi üretme, var olan olguyu anlama, açılama ve kuram geliştirmeye kadar bilgi üretmeyi amaçlayan temel araştırmalar, değişkeni daha iyi anlamak ve değişkenle ilgili eksik bilgileri tamamlamak için yapılır (Balcı, 2015; Büyüköztürk, Kılıç-Çakmak, Akgün, Karadeniz ve Demirel, 2008; Karasar, 2005). Keşfedici araştırmalar ise konuyla ilgili araştırmacının merakını gidermek, konuyla ilgili detaylı bilgiyi elde etmek için ön bilgiyi elde etmek ve sonraki araştırmalarda kullanılabilecek veri toplama aracı geliştirebilmek için yapılır (Stebbins, 2001). Bu çalışmada da "örgütsel demokrasi" kavramını tanımlanmak, açıklamak, bu kavrama ilişkin bilgi üretmek ve sonraki araştırmalarda kullanılabilecek veri toplama aracı geliştirmek amaçlandığı için "temel araştırmalardan keşfedici araştırma yöntemi" kullanılmıştır.

\section{Çalışma Grubu}

Bu çalışmada iki farklı katılımcı grubuna ulaşılmıştır. Pilot uygulamada belirlenen örneklem grubu, Çankırı ili Millî Eğitim Müdürlügünnde görev yapan toplam 378 öğretmenden oluşmaktadır. Örneklem seçiminde farklı okul türlerinin temsiliyetini sağlamak üzere küme örnekleme yöntemi kullanılmıştır. Çankırı ilindeki okul öncesi, ilk, orta ve lise eğitim kurumlarında görev yapan öğretmen sayıları küme olarak listelenmiş ve örnekleme alınacak öğretmenler her kümeden tesadüfi olarak seçilmiştir. Araştırmanın pilot uygulamasına katılan öğretmenlerin 19 tanesi (\%5) okul öncesi eğitim, 116 tanesi $(\% 30,7)$ ilkokul, 86 tanesi $(\% 22,8)$ ortaokul ve 157 tanesi $(\% 41,5)$ lise kurumlarında görev yapmaktadır. İkinci aşama katılımcı grubunu ise hazırlanan çevrim içi anket ile farklı illerde görev yapan toplam 348 öğretmen oluşturmaktadır. Araştırmanın ikinci aşamasına katılan öğretmenlerin 19 tanesi (\%6) okul öncesi eğitim, 116 tanesi (\%33) ilkokul, 65 tanesi (\%19) ortaokul ve 148 tanesi (\%42) lise kurumlarında görev yapmaktadır.

\section{Veri Toplama Aracının Geliştirilmesi}

Okullarda örgütsel demokrasi algısını ölçmek amacıyla geçerli ve güvenilir bir ölçek geliştirmek için öncelikle ilgili alanyazın incelenmiş, okullarda örgütsel demokrasiye ilişkin genel bir kuramsal çerçeve çizilmiştir. Ayrıca alanda çalışan öğretmenler ile okullarda örgütsel demokrasiye 
ilişkin algıları ile ilgili olarak görüşmeler de yapılmıştır. Çizilen kurumsal çerçeve ve alanda çalışan öğretmenlerin görüşleri dikkate alınarak toplam 41 maddelik bir madde havuzu oluşturulmuştur. Hazırlanan maddelerin anlam, kapsam, anlaşılırlık ve açıklık açısından değerlendirilmesi için, içinde bir dil uzmanının da yer aldığı, konu alanı uzmanı olan toplam 15 akademisyene gönderilmiştir. Konu alanı uzmanları tarafından yapılan inceleme sonucunda aynı hedefi ölçtüğü veya örgütsel demokrasi kavramı ile ilgili olmadığı düşünülen 4 madde havuzdan çıkarılmıştır. Hazırlanan 37 maddelik taslak ölçek 10 tane alanda çalışan öğretmen tarafından anlam açısından tekrar incelenmiş ve taslak ölçekte anlam kaymaları olmadığı sonucuna varılmıştır. Ölçeğin doldurulma süresinin en fazla 10 dakika olduğu gözlenmiştir. Bu doğrultuda hazırlanan 37 maddelik taslak ölçek yönergede yer alan ifadelere son hâli verilerek pilot uygulamaya hazır hâle getirilmiştir. OÖD Ölçeği, "1-Hiç Katılmıyorum”, “2Katılmiyorum", “3-Orta Derecede Kat1liyorum", "4-Katıliyorum”, “5-Kesinlikle Kat1liyorum" biçiminde beş dereceli Likert formatında hazırlanmıştır.

\section{Verilerin Analizi}

Araştırma kapsamında toplanan verilerin analizinden önce her iki veri seti üzerinde bazı incelemeler yapılmıştır. Araştırmanın pilot uygulaması için toplanan verilerin normal dağılıma uygun olup olmadığını değerlendirmek üzere betimsel istatistikler ve saçılım diyagramları incelenmiştir. Pilot uygulamadan elde edilen verilerin ortalaması 3.93, ortancası 3.94, çarpıklık katsayısı -.70, basıklık katsayısı 1.35 olarak bulunmuştur. Ortalama ve ortancanın birbirine yakın olması, basıklık ve çarpıklık değerinin \pm 2 aralığında olması verilerin normal dağılıma yakın olduğunu göstermektedir. Ayrıca incelenen saçılım diyagramında da verilerin normal dağılıma yakın olduğu gözlenmiştir. Pilot uygulamanın örneklem büyüklügünün faktör analizine uygun olup olmadığına karar vermek üzere Kaiser-Meyer-Olkin (KMO) ve Bartlett Küresellik Testi yapılmıştır. Pilot uygulamadan elde edilen verilerin KMO değeri .97 olarak hesaplanmıştır. Diğer yandan Bartlett Küresellik Testi ise istatistiksel olarak anlamlı çıkmıştır ( $\chi 2$ = 14329.757, p < .001). Örneklem büyüklüğünün faktör analizi yapmaya uygunluğunun belirlenmesinde kullanılan KMO değerinin, 1'e yaklaştıkça mükemmel, 0.50'nin altında ise kabul edilemez olduğu ifade edilmektedir (Tavşancıl, 2005). Pilot uygulamalardan elde edilen verilerin çoklu bağlantı varsayımlarını karşılama durumlarını incelemek içinse ölçek maddeleri arasındaki korelasyon değerleri incelenmiştir. Ölçek maddeleri arasındaki korelasyon değerleri incelendiğinde, en yüksek korelasyon değerinin .81 olduğu görülmüştür. Veri setinde maddeler arası korelasyon değerinin .90 üzeri olması durumunda çoklu bağlantı olduğu ifade edilmektedir (Şencan, 2005; Tabachnick ve Fidell, 2017). Pilot uygulama verilerinin incelenmesi sonucunda verilerin normal dağıldığı, örneklem büyüklügünün faktör analizi yapmaya uygun olduğu ve maddeler arası çoklu bağlantı olmadığı sonucuna varılmıştır. 
Araştırmanın ikinci aşaması için toplanan veriler üzerinde de aynı incelemeler yapılmıştır. Verinin normal dağılıma uygun olup olmadığını belirlemek için betimsel istatistikler ve saçlım diyagramları, örneklem büyüklügünün faktör analizine uygun olup olmadığını belirlemek için KaiserMeyer-Olkin (KMO) ve Bartlett Küresellik Testi ve verilerin çoklu bağlantı varsayımlarını karşılama durumlarını incelemek içinse ölçek maddeleri arasındaki korelasyon değerleri incelenmiştir. İkinci aşamada elde edilen verilerin ortalaması 3.70, ortancası 3,84, çarpıklık katsayısı -.65, basıklık katsayısı .15 olarak bulunmuştur. İkinci uygulamadan elde edilen verilerin KMO değeri .97 ve Bartlett Küresellik Testi istatistiksel olarak anlamlı ç1kmıştır $(\chi 2=12765.624, p<.001)$. Ayrıca maddeler arası korelasyon değeri en yüksek .72 olarak belirlenmiştir. Çalışmanın ikinci aşaması için toplanan verilerin de normal dağıldığı̆, örneklem büyüklüğünün faktör analizi yapmaya uygun olduğu ve maddeler arası çoklu bağlantı olmadığı sonucuna varılmıştır.

Çalışmada kullanılan her iki veri setinin analiz yapmaya uygun olduğuna karar verildikten sonra, pilot uygulamadan elde edilen veriler ile Açımlayıcı Faktör Analizi (AFA) ve Doğrulayıcı Faktör Analizi (DFA), ikinci aşamada elde edilen veriler ile de Doğrulayıcı Faktör Analizi (DFA) yapılmıştır. AFA kapsamında maddelerin aynı yapıyı ölçüp ölçmediğine karar vermek için Temel Bileşenler Analizi kullanılmıştır. Faktör sayısını belirlemek için öz-değerin 1'in üzerinde olma kuralı dikkate alınmış, yamaç birikinti grafiği incelenmiş ve değişkenler arasındaki ilişkiden dolayı eğik döndürme yöntemi kullanılmıştır. Madde seçerken ve maddenin söz konusu yapıyı ölçüp ölçmediğine karar verirken, her bir maddenin tek bir yapı altında toplanmasına, maddelerin madde faktör yük değerinin .30 'un üstünde olmasına, iki faktörde yer alan maddelerin faktör yük değerleri arasında en az .10’luk bir fark olmasına dikkat edilmiştir. Ayrıca maddelerin madde toplam korelasyon değerleri incelenmiş, madde toplam korelasyon değerleri .50'nin altında olanlar ölçekten çıkarılmıştır (Büyüköztürk, 2007; Tabachnick ve Fidell, 2017; Tavşancıl, 2005). AFA, SPSS 23.00 istatistik paket programı kullanılarak gerçekleştirilmiştir.

AFA sonucunda gözlenen faktör yapısının uygunluğu, çalışmanın ikinci aşamasında toplanan veriler ile değişkenler arasındaki yapının yeterli uyum indeksleri verip vermediğini belirlemek ve ölçeğin yapı geçerliğini doğrulamak için kullanılan bir yöntem olan DFA ile test edilmiştir (Tabachnick ve Fidell, 2017). Doğrulayıcı faktör analizinde test edilen modelin araştırmadan elde edilen veriler ile uyumlu olup olmadığını ortaya koymak üzere çeşitli uyum indeksleri referans alınmış, alanyazında kabul gören uyum iyiliği ölçütleri kullanılmıştır. Bu çalışmada önerilen modelin uygunluğunu değerlendirmek amacıyla ki kare değerinin serbestlik derecesine oranın yanı sıra İyilik Uyum İndeksi (GFI), Yaklaşık Hataların Ortalama Karekökü (RMSEA), Karşılaştırmalı Uyum İndeksi (CFI) ve Normlaştırılmış Uyum İndeksi (NFI) ve Standardize Edilmiş Artık Ortalamaların Karekökü (SRMR) kullanılmıştır. Ki kare değerinin serbestlik derecesine bölünmesiyle elde edilen değerin, ölçüm sayısı 
250'den büyük örneklemlerde 5'tek küçük, ölçüm sayısı 250'den küçük örneklemlerde 3'ten küçük olması "mükemmel uyuma" işaret etmektedir (Byrne, 2011). RMSEA değerinin 0.08'ten küçük olması "iyi uyuma", GFI, NFI, CFI ve gibi uyum istatistiklerinin ise 0.90 ve üzerinde olması "iyi uyuma", 0.95 ve üzerinde olması ise "mükemmel uyuma" işaret etmektedir. SRMR değerinin ise 0.5 ila 0.8 arasında olması ise "iyi uyum" olduğunun göstergesidir (Çokluk, Şekercioğlu ve Büyüköztürk, 2012; Hooper, Coughlan ve Mullen, 2008; Hu ve Bentler, 1999; Jöreskog ve Sörborn, 1993). DFA, LISREL88 istatistik paket programı kullanılarak gerçekleştirilmiştir.

Ölçekte yer alan maddelerin ölçtükleri özellik bakımından kişileri ayırt etmede ne düzeyde yeterli olduklarının belirlenmesinde \%27'lik alt ve üst grup ortalamaları karşılaştırılmıştır. Aynı zamanda ölçeğin iç güvenirliğini saptamak amacıyla Cronbach-Alfa, iç tutarlılık katsayısı hesaplanmıştır.

\section{Bulgular}

Pilot uygulamadan elde edilen verilerle, 37 madde üzerinden AFA'ya başlanılmıştır. Yapılan ilk incelemede, maddelerin madde toplam korelasyon katsayılarına bakılmıştır. Yapılan incelemede 5. maddenin (Okul yönetimi karar verirken öğretmenlerin fikrini alıp yine kendi istekleri doğrultusunda hareket eder.) madde toplam korelasyon değerinin .019 olduğu gözlenmiş ve bu maddenin ölçekten çıkarılmasına karar verilmiştir. 36 madde üzerinde AFA tekrarlanmıştır. AFA sırasında ölçekte yer alan ve birbirinden bağımsız alt faktörleri belirlemek amacıyla Varimax dik döndürme yöntemi kullanılmıştır. Ayrıca ölçeğe ait faktör sayısının belirlenmesinde ise öz-değer (Eigenvalue) ile çizgi grafiğinden (Scree Plot) yararlanılmıştır. Yapılan analize ilişkin yamaç grafiği (Scree Plot) Şekil 1'de verilmiştir.

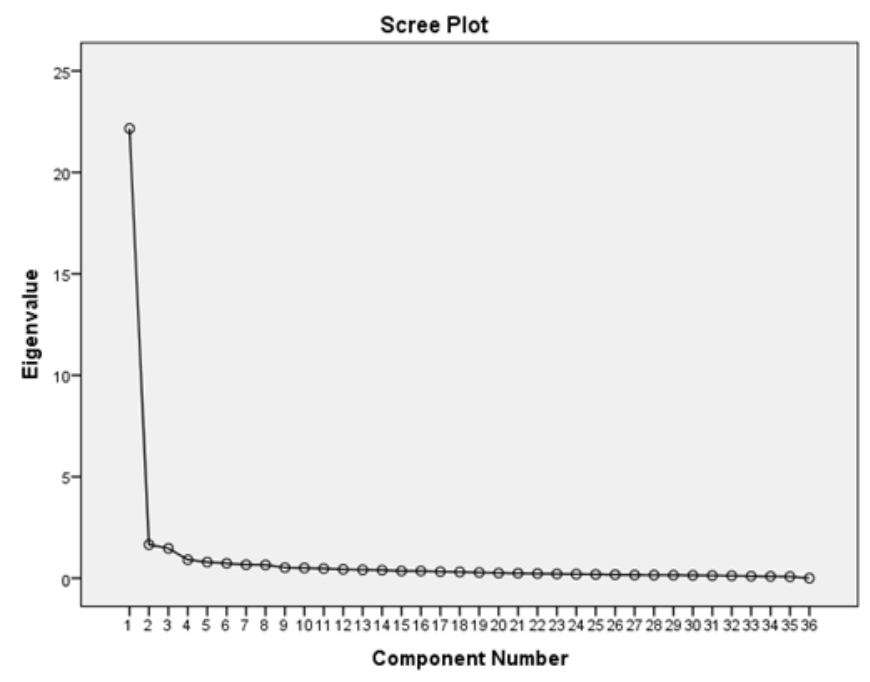

Şekil 1. Yamaç Grafiği (Scree Plot) 
Faktör yüklerinin .40 'tan yüksek olması ve birden fazla faktörde yük değeri olan maddede iki faktör arasındaki değerin en az .10 olmasına dikkat edilmiştir (Tabachnick ve Fidell, 2017). Analiz sonucunda binişik ve ilgisiz faktörleşen herhangi bir maddeye rastlanmamıştır. OÖD Ölçeği'ne ilişkin yapılan AFA sonuçları Tablo 1'de sunulmuştur.

Tablo 1. Okullarda Örgütsel Demokrasi Ölçeği'nin Açımlayıcı Faktör Analizi Sonuçları

\begin{tabular}{|c|c|c|c|c|}
\hline Mad. & Ifadeler & Faktör1 & Faktör2 & Faktör3 \\
\hline 20 & Okul yönetimi, kararları tarafsız bir şekilde alır. & .82 & & \\
\hline 19 & Okul yönetimi alınan her kararı öğretmenlere ayrım yapmaksızın uygular. & .82 & & \\
\hline 21 & $\begin{array}{l}\text { Okul yönetimi okulla ilgili görev ve sorumlulukların öğretmenlere dağıtımında } \\
\text { adil davranır. }\end{array}$ & .80 & & \\
\hline 18 & $\begin{array}{l}\text { Okul yönetiminin, öğretmenlerin değerlendirmesi ile ilgili standart kriterleri } \\
\text { vardır. }\end{array}$ & .78 & & \\
\hline 27 & Okul yönetimi her öğretmene eşit mesafede davranır. & .71 & & \\
\hline 10 & Okul yönetimi yürüttüğü bütün işlerde şeffaflık ilkesine göre hareket eder. & .70 & & \\
\hline 14 & Okul yönetimi öğretmen değerlendirme sürecini șeffaflık ilkesine göre yürütür. & .69 & & \\
\hline 17 & Okul yönetimi maddi ve manevi ödüllerin dağıtımında adil davranır. & .69 & & \\
\hline 22 & $\begin{array}{l}\text { Okul yönetimi okulda ders dışı etkinliklerin (sorumlulukların) öğretmenlere } \\
\text { dağıtımında adil davranır. }\end{array}$ & .67 & & \\
\hline 16 & Okul yönetimi öğretmenlerin görev dağılımını liyakat esaslarına göre yapar. & .66 & & \\
\hline 15 & Okul yönetimi alınan kararlarda şeffaflık ilkesini uygular. & .65 & & \\
\hline 36 & $\begin{array}{l}\text { Okul yönetimi, öğretmenlerin yönetimin uygulamaları hakkında yaptığı } \\
\text { eleştirileri dikkate alır. }\end{array}$ & .65 & & \\
\hline 37 & $\begin{array}{l}\text { Okul yönetimi okulda herhangi bir başarısızlık söz konusu olduğunda } \\
\text { sorumluluğu üstlenir. }\end{array}$ & .64 & & \\
\hline 35 & $\begin{array}{l}\text { Öğretmenler yönetimin yanlış buldukları karar ve politikalarını rahatlıkla } \\
\text { eleştirebilir. }\end{array}$ & .63 & & \\
\hline 9 & $\begin{array}{l}\text { Okul yönetimi öğretimle ilgili okul bütçesinin kullanımı konusunda } \\
\text { öğretmenlerle birlikte karar alır. }\end{array}$ & .63 & & \\
\hline 29 & Okul yönetimi öğretmenlerin taleplerine zamanında yanıt verir. & .61 & & \\
\hline 13 & Okul yönetimi çift yönlü ve açık iletişimi destekler/iletişime önem verir. & .57 & & \\
\hline 24 & Okul yönetimi öğretmenler arasında dil, din, ırk vb. ayrımı yapmamaktadır & & .78 & \\
\hline 32 & Okul yönetimi dönem ve yılsonunda hedeflere ulaşabilme düzeyini açıklar. & & .75 & \\
\hline 33 & Okul yönetimi okul bölgesinde yer alan kamu kurumlarıyla iletişim hâlindedir. & & .72 & \\
\hline 31 & Okul yönetimi dönem ve yılsonunda hedefleri açıklar. & & .71 & \\
\hline 23 & Okul yönetimi cinsiyete dayalı ayırım yapmamaktadır. & & .69 & \\
\hline 34 & Okul yönetimi bilgi edinme talebini normal karşılamaktadır. & & .69 & \\
\hline 25 & Okul yönetimi, öğretmenlerin politik düşüncelerine göre ayrımcllık yapmaz & & .68 & \\
\hline 28 & Okul yönetimi alınan kararların gerekçelerini açıklar. & & .66 & \\
\hline 30 & Okul yönetimi öğretmenlerin karşılanamayan taleplerinin gerekçelerini açıklar. & & .62 & \\
\hline 26 & Okul yönetimi, toplantılarda önerinin kimden geldiğine değil, niteliğine bakar. & & .59 & \\
\hline 12 & Okul yönetimi, gerekli durumlarda bilgilendirme toplantıları düzenler. & & .57 & \\
\hline 11 & $\begin{array}{l}\text { Okul yönetimi, toplantılarda herkesin görüşlerini açıkça ifade etmesine fırsat } \\
\text { verir. }\end{array}$ & & & .68 \\
\hline 2 & Okul yönetimi kararlarda fikri alınan kişilere uygulamada sorumluluk verir. & & & .67 \\
\hline 3 & $\begin{array}{l}\text { Okul yönetimi okulu ilgilendiren bir karar alırken çoğunluğun görüşlerini } \\
\text { dikkate alır. }\end{array}$ & & & .65 \\
\hline 7 & Okul yönetimi okuldaki sorunların tespitinde öğretmenlerin fikrini alır. & & & .65 \\
\hline 6 & Okul yönetimi, okulda yenilik yapılacağı zaman öğretmenlerin fikrini alır & & & .61 \\
\hline 8 & Okul yönetimi okuldaki sorunların çözümünde öğretmenlerin fikrini alır. & & & .54 \\
\hline 4 & Okul yönetimi hoşlarına gitmese de çoğunluğun verdiği kararlara saygı gösterir. & & & .53 \\
\hline 1 & $\begin{array}{l}\text { Okul yöneticimi karar verme sürecinde kararın sonuçlarından etkilenenlerin } \\
\text { fikrini alır. }\end{array}$ & & & .52 \\
\hline \multicolumn{2}{|r|}{ Özdeğer } & 21.84 & 1.69 & 1.52 \\
\hline \multicolumn{2}{|c|}{ Açkılanan Varyans } & $\% 31.24$ & $\% 24.90$ & $\% 13.44$ \\
\hline \multicolumn{2}{|c|}{ Cronbach Alpha } & .97 & .95 & .84 \\
\hline \multicolumn{2}{|c|}{ Cronbach Alpha Toplam } & & .97 & \\
\hline \multicolumn{2}{|c|}{ Açıklanan Toplam Varyans } & & $\% 69.5$ & \\
\hline
\end{tabular}


Yapılan AFA sonucunda OÖD Ölçeği'nin, özdeğeri 1'den büyük ve faktörlerin hepsinin birlikte toplam varyansın \%69,59'unu açıklayan üç faktörlü bir yapı sergilediği ortaya çıkmıştır. Ölçeğin tüm faktör yükleri anlamlıdır. Alt boyutlar için faktör yüklerinin aralıkları şu şekilde değişiklik göstermektedir: Eşitlik ve adalet boyutu için .82 ile .57 , hesapverebilirlik boyutu için .78 ile .57 ve katılım boyutu için .68 ile .52 . Ayrıca OÖD Ölçeği'nin birinci faktöre ilişkin Cronbach Alpha değeri .97, ikinci faktöre ilişkin Cronbach Alpha değeri .95 ve üçüncü faktöre ait Cronbach Alpha değerinin .84 olduğu ortaya çıkmıştır.

Pilot uygulamada OÖD Ölçeği'nin; eşitlik ve adalet, hesapverebilirlik ve katılım olmak üzere üç alt boyuttan oluştuğu gözlenmiştir. Pilot uygulamadan elde edilen verilerle, ölçeğin faktör yapısını test etmek için Doğrulayıcı Faktör Analizi (DFA) de yapılmıştır. Buna göre ölçek orta düzeyde bir uyum iyiliği göstermektedir $\left(\chi^{2}=2834.20, \mathrm{sd}=580, \mathrm{p}<.05 ; \mathrm{X} 2 / \mathrm{sd}=4.8 ; \mathrm{NNFI}=.96 ; \mathrm{CFI}=.96\right.$; RMSEA = .08).

\section{Doğrulayıcı Faktör Analizi Sonuçları}

Yapılan AFA sonucunda elde edilen 36 madde ve 3 faktör yapısının yeterli uyum indeksi gösterip göstermediğini doğrulamak için araştırmanın ikinci aşamasında toplanan verilerle DFA yapılmıştır. İkinci aşama için hazırlanan ölçek formunda maddeler tekrar numaralandırılmıştır. Yapılan DFA'ya ait yol şeması Şekil 2'de gösterilmiştir.

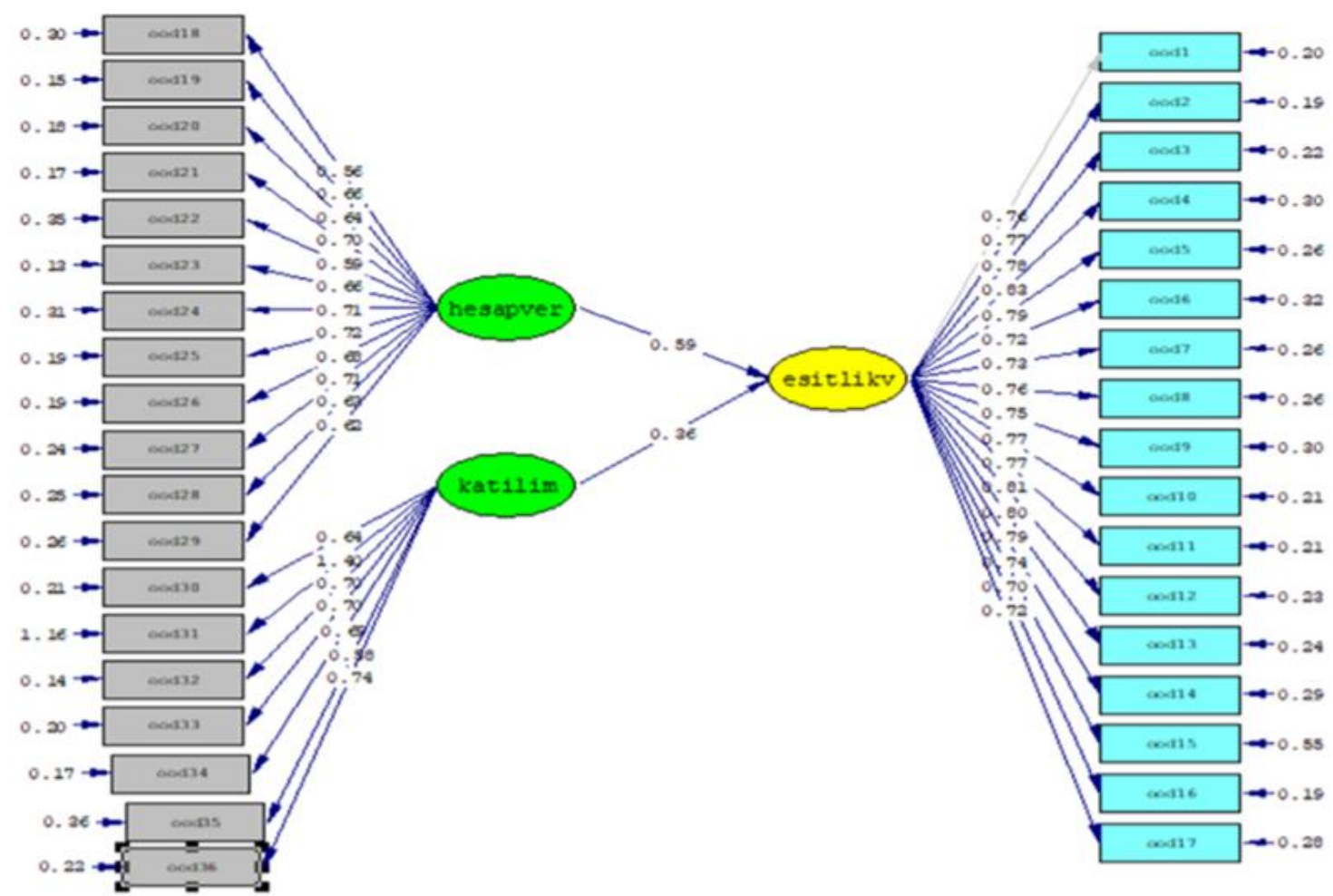

Şekil 2. OÖDÖ’nin Alt Boyutlarının Birbiriyle İlişkisini Gösteren Üç Faktörlü Model 
Şekil 2'de görüldüğü gibi, yapılan yol analizinde üç farklı örtük değişkenden oluşan bir ölçme modeli ortaya çıkmıştır. Gözlenen değişkenler ile gizil değişkenler arasındaki korelasyonu ifade eden Lambda $(\lambda)$ değerleri oldukça yüksek çıkmıştır. Lambda değerlerinin yüksek olması gizil ve gözlenen değişken arasında güçlü bir ilişkinin göstergesidir (Çokluk vd., 2012).

Modelin doğrulanmasına ilişkin yapılan analizler sonucunda elde edilen uyum indeks değerleri ve bu değerler için kabul kesme noktaları dikkate alınarak yapılan değerlendirme sonuçları Tablo 2'de verilmiştir.

Tablo 2. Doğrulayıcı Faktör Analizleri Uyum İndeksleri

\begin{tabular}{|c|c|c|c|c|c|c|c|c|}
\hline Model & $X^{2}$ & $s d$ & $X^{2} / s d$ & RMSEA & SRMR & NFI & CFI & GFI \\
\hline $\begin{array}{l}3 \text { fak. } \\
\text { yap1 }\end{array}$ & 2779.28 & 591 & $\begin{array}{c}4.7 \\
\text { Mükemmel } \\
\text { Uyum }\end{array}$ & $\begin{array}{c}.07 \\
\text { Iyi } \\
\text { Uyum }\end{array}$ & $\begin{array}{c}.06 \\
\text { Mükemmel } \\
\text { Uyum }\end{array}$ & $\begin{array}{c}.96 \\
\text { Mükemmel } \\
\text { Uyum }\end{array}$ & $\begin{array}{c}.96 \\
\text { Mükemmel } \\
\text { Uyum }\end{array}$ & $\begin{array}{c}.92 \\
\text { Mükemmel } \\
\text { Uyum }\end{array}$ \\
\hline
\end{tabular}

Tablo 2 incelendiğinde, kurulan modelde elde edilen uyum indekslerinin kesme noktalarına eşit ve yakın olması modelin yapısının doğrulandığını göstermektedir. Doğrulanan faktör yapısında maddeler tekrar numaralandırılmış ve 1 ila 17. maddelerden oluşan ilk faktöre "eşitlik ve adalet", 18 ila 30. maddelerden oluşan ikinci faktöre "hesapverebilirlik" ve 31 ila 36. maddelerden oluşan üçüncü faktöre "katılım" olarak adlandırılabileceğine karar verilmiştir.

\section{Ölçeğin Güvenirliği ve Ayırt Ediciliği}

OÖD Ölçeği'nin güvenirliğini hem genel olarak hem de alt faktörler bazında incelemek için Cronbach Alpha korelasyon katsayıları hesaplanmıştır.

Tablo 3. Ölçek Faktörlerine İlişkin Korelasyon Katsayıları

\begin{tabular}{lcccccc}
\hline & $X$ & SS & Cronbach Alpha & $\mathbf{1}$ & $\mathbf{2}$ & $\mathbf{3}$ \\
\hline 1. Eşitlik ve Adalet & 3.83 & .77 & .97 & 1 & & \\
2. Hesapverebilirlik & 4.10 & .65 & .95 & $.86^{*}$ & 1 & \\
3. Kat1lim & 3.96 & .68 & .80 & $.73^{*}$ & $.75^{*}$ & 1 \\
4. OÖD toplam & 3.95 & .62 & .97 & $.97^{*}$ & $.94^{*}$ & $.83^{*}$ \\
\hline
\end{tabular}

Tablo 3'te izlenebileceği gibi gerek ölçeğin tamamı gerekse alt boyutlar için Cronbach Alpha güvenirlik katsayısı oldukça yüksektir. Ayrıca faktörler arasında .90 'ın üzerinde ilişki gözlenmemiş olması geliştirilen ölçme aracında çoklu bağlantı olmadığının göstergesidir (Çokluk vd., 2012).

Ölçeğin ayırt edicilik gücünü test etmek üzere alt ve üst \%27'lik dilimlerden iki grup oluşturularak bu iki grubun ölçek puanları arasındaki farklılaşma bağımsız örneklem $t$ testi ile incelenmiştir. Tablo 4'te ayırt edicilik için t testi sonuçları paylaşılmaktadır.

Tablo 4. Ayırt Edicilik için T-testi

\begin{tabular}{cccccc}
\hline & Örgütsel Demokrasi & $\boldsymbol{n}$ & $\boldsymbol{X}$ & SS & $\boldsymbol{t}$ \\
\hline \multirow{2}{*}{ Ölçek } & Düşük & 94 & 2.27 & .57 & \multirow{2}{*}{$42.16^{*}$} \\
& Yüksek & 94 & 4.02 & .50 & \\
\hline
\end{tabular}


Tablo 4'te de izlenebileceği gibi, Örgütsel Demokrasi Ölçeği'nin tamamı için öğretmen algısı düşük ve yüksek gruplarda yer alan öğretmenler arasındaki farklılaşmanın istatistiksel olarak anlamlı olduğu görülmektedir. Buna göre ölçeğin ayırt edicilik gücü yüksek bulunmuştur.

\section{Tartışma}

Bu çalışmanın sonucunda kâr amacı gütmeyen okullarda demokrasi kültürü aracılığıyla toplum üzerinde daha geniş ve sürdürülebilir etkiler üretilebileceği varsayımından hareketle okullarda demokrasinin genel görünümü ortaya koyan geçerli ve güvenilir bir ölçme aracı geliştirilmiştir. Araştırmalar hiyerarşik organizasyon biçimlerinin örgütlerde hiyerarşinin yönetim tarafından baskıcı ve kontrol edici uygulamaları mümkün kıldığını ve desteklediğini (Alvesson ve Willmott, 1996), mevcut eşitsizlikleri sürdürdügünü (Acker, 1990) ve karar vermeyi yavaşlatabilecek birden çok engel yarattığını (Weber vd., 2009) ortaya koymuştur. Kamu hizmeti sunan okullarda örgütsel demokrasinin artırılmasıyla daha hesapverilebilir, üyelerinin ihtiyaç ve çıarları gözetilebilir ve daha etkili karar verme biçimleri yaratılabilir (King ve Griffin, 2019).

“Okullarda Örgütsel Demokrasi” Ölçeği kavramsal açısından ele alındığında, örgütsel demokrasinin ilkeleri (katılım, eleştiri, hesapverebilirlik, şeffaflık, eşitlik ve adalet) göz önünde bulundurularak geliştirilmiştir. Ancak öğretmenler eleştiri, eşitlik ve adalet ile ilgili maddeleri tek boyut altında değerlendirmiştir. Aynı şekilde hesapverebilirlik ve şeffaflık ile ilgili maddeler de tek boyut altında toplanmıştır. Böylece yapılan analiz sonucunda ölçek üç boyut altında toplanmıştır. Bunun nedeni öğretmenlerin söz konusu kavramları kesin sınırlarla birbirinden ayrılmadığına inanmaları olabilir. Nitekim Rawls (1993), adalet teorisini özgürlük ve eşitlik bağlamında açıklar. Adalet, herkese eşit fırsatlar (fırsat eşitliği) ve gereğince herkese açık tutulan mevkiler verme yoluyla sağlanabilir. Rawls (2017), her eşitliğin adalet getirmediğine, adaletin sağlanabilmesi için kaynakların dengeli bir biçimde dağıtılması gerektiğine vurgu yapmıştır. Aynı şekilde, adalet özgürlük anlayışı içerisinde herkesin fikirlerini özgür bir şekilde ifade edebilmesi ile sağlanabilir. Bu da bireylerin eleştiri yapabilme hakkını vurgular. Dolayısıyla öğretmenlerin adalet, eşitlik ve eleştiri kavramlarını tek bir boyut altında değerlendirmeleri anlaşılırdır. Benzer şekilde hesapverebilirlik kavramı da açıklık ve şeffaflık ilkeleri ile çok yakından ilgilidir. Yönetimde şeffaflığın temelini, herkesin ihtiyaç duyduğu bilgiye ulaşılabilmesi oluşturmaktadır. Yönetimde şeffaflık için etkili ve iyi işleyen hesap verme sistemi, hesap verebilirlik için de şeffaf politikaların bulunması gerekmektedir (Mulgan, 2000). Bu nedenle öğretmenler şeffaflık ve hesapverebilirlik kavramlarını ayrı düşünmemişlerdir.

Örgütsel demokrasinin bir diğer önemli ilkelerinden biri de "katılım" ilkesidir. Geliştirilen ölçekte katılımcılar örgütsel demokrasinin "katılım" ilkesini de ayrı bir yapı olarak görmüşlerdir. Türkiye gibi eğitim sistemi merkeziyetçi bir yönetim anlayışı ile yürütülen bir ülkede (Şişman ve Turan, 2003) öğretmenlerin "katılım" ilkesini ayrı bir yapı olarak algılamalarının nedeni, 
öğretmenlerin karar alma yetki ve sorumluluğunu okul yönetiminin yetki paylaşımına gitmesi (Ekşi ve Maya, 2011) olarak düşünmesi olabilir. Bu bağlamda geliştirilen ölçekte "katılım" ilkesine ilişkin ayrı bir boyut olarak algılanması manidardır.

Geliştirilen ölçekte bir diğer dikkat çekici konu eşitlik ve adalet boyutu, hesapverebilirlik ve katılım boyutlarındaki bazı maddelerin görünüşte var olan yapıyı tam yansıtmadığı yönündedir. Örneğin "Okul yönetimi yürüttüğü bütün işlerde şeffaflık ilkesine göre hareket eder.” maddesi görünüşte hesapverebilirlik boyutunda çıkması gereken bir madde olarak düşünülebilir. Ancak yapılan AFA sonucunda bu madde eşitlik ve adalet boyutunda çıkmıştır. Bunun nedeni AFA'nın altta yatan örtük psikolojik yapıyı ortaya çıkarmış olmasıdır (Erkuş, Sünbül, Ömür-Sünbül, Yormaz ve Aşiret, 2017). Başka bir ifade ile katılımcıların "şeffaflık" ile ilgili algıları, daha çok "eşitlik ve adalet" ile ilgili kanılara yakındır. Madde evreninden yapıyı en iyi temsil edenlerin örneklenebilmesi için seçilen maddelerin madde-toplam test/ölçek korelasyonları incelendiğinde ilgili maddelerin belirlenen yapıya katkılarının ne kadar olduğu belirlenmiş ve bu maddelerin oluşturdukları yapıların her birinin açıkladığı varyanslar ve özdeğerleri belirlenen üç yapının genel yapı içindeki paylarına kanıt sunmuştur. Dolayısıyla farklı boyutlar altında değerlendirilmesi gerektiği düşünülen maddeler aslında başka bir yapıyı açıklamıştır.

\section{Sonuç ve Öneriler}

Okullarda öğretmen görüşlerine göre örgütsel demokrasi düzeyini ölçmek için geçerli ve güvenilir bir ölçme aracı geliştirmeye odaklanan bu çalışmada, öncelikle literatür taramasına ve öğretmen görüşlerine dayalı olarak taslak ölçek oluşturularak uzman görüşüne sunulmuştur. Uzmanlardan gelen görüşler doğrultusunda son hâli verilen ölçeğin pilot uygulaması yapılmış, pilot uygulamadan elde edilen verilerle de ölçeğin yapı geçerliliğini ortaya koymak için açımlayıcı faktör analizi yapılmıştır. Açımlayıcı faktör analizi sonucunda madde faktör yük değeri düşük olan bir madde ölçekten çıkarılmış ve ölçek ana uygulama için faklı bir örneklem grubuna uygulanmıştır. Ana uygulamadan elde edilen veriler ile kurulan modeli doğrulamak için doğrulayıcı faktör analizi yapılmıştır. Yapılan analiz sonucunda kurulan modelin uyum indekslerinin kesme noktalarına eşit ve yakın olması nedeniyle modelin yapısı doğrulanmıştır. Ölçeğinin güvenirliğini belirlemek için Cronbach Alpha korelasyon katsayıları hesaplanmış, hesaplanan katsayısın yüksek olduğu gözlenmiştir. Son olarak ölçeğin madde ayırt ediciliğini belirlemek için alt üst \%27'lik dilimlerden oluşturulan iki grup arasında farklılaşmaya bakılmış ve bu farklılaşmanın anlamlı olduğu gözlenmiştir. Sonuçta, okullarda öğretmen görüşlerine göre örgütsel demokrasi düzeyini ölçmek için eşitlik ve adalet, hesapverebilirlik ve katılım olmak üzere üç boyutlu ve toplam 36 maddeden oluşan geçerli ve güvenilir bir ölçme aracı geliştirilmiştir. 
Okullarda örgütsel demokrasi ölçeği geliştirilirken, dünya literatüründen faydalanılmıştır. Bu durum ölçeğin evrensel niteliğini güçlendirmiş olsa da belli bir kültür için bir kavramı ölçmek amacıyla geliştirilmiş bir ölçme aracının başka herhangi bir kültürde "olduğu gibi" kullanılmasının kavram hakkında karar vermede sakıncalar yaratacağı (Erkuş ve Selvi, 2019) düşünüldüğünde bu ölçme aracını başka kültürlerde kullanmak için ölçme aracının adaptasyonunun yapılması önerilmektedir.

Çalışmanın örneklem grubunu kamuda çalışan öğretmenler oluşturmaktadır. Dolayısıyla öğretmenlerin iş güvencesi bulunmaktadır. Özel okullarda çalışan öğretmenlerin iş güvencesi olmadığı için örgütsel demokrasi algısı farklı olabilir. Dolayısıyla geliştirilen ölçek özel okullarda çalışan öğretmen grubu dikkate alınarak farklı özellikteki örneklemlerle yapılacak çalışmalarda ölçeğin geçerlik ve güvenirliğinin test edilmesi gerekebilir.

Okullarda örgütsel demokrasi algısını ortaya koymak için geliştirilen söz konusu ölçek ile okulların ne kadar demokrasinin temel ilkeleri ile yönetildiği belirlenebilir, ayrıca demokrasi ilkeleri ile yönetilen okullarda öğretmenlerin örgütsel bağlılıkları, örgütsel güven düzeyleri, motivasyonları, tükenmişlikleri arasındaki ilişkiler de incelenebilir. Diğer taraftan örgütsel demokrasi ile yönetilen okulların öğrenci başarısı üzerinde ne tür bir katkıya sahip olabileceği de incelemeye değer bir konudur.

Geliştirilen ölçek ile politika yapıcılar, okullarda sunulan hizmetin sunumundaki geleneksel yönetimci anlayışın öngördüğü verimlilikle ilgili kaygıların ötesinde, okullarda demokrasi kültürünün yaratılmasında daha geniş bir ekosistemin nasıl oluşturabileceği ve bu ekosistemde okul müdürlerinin hangi rollere sahip olması gerektiği ile ilgili olarak derinlemesine bir anlayış geliştirebilir. Ayrıca politika geliştiriciler, geliştirilen ölçeğin uygulanmasıyla, okulda demokrasi kültürünün yaratılması için okul müdürlerinin daha geniş sorumluluk alarak okulun yeniden yapılandırılmasını sağlayabilirler.

\section{Kaynaklar}

Acker, J. (1990). Hierarchies, jobs, bodies: A theory of gendered organizations. Gender \& Society(4), 139158.

Ahmend, K., Adeel, A., Ali, R. \& Rehmann, R. U. (2019). Organizational democracy and employee outcomes: The mediating role of organizational justice. Business Strategy and Development, 2(3), 204-219.

Alvesson, M. \& Willmott, H. (1996). Making sense of management: A critical introduction. London, England: SAGE.

Balc1, A. (2015). Sosyal bilimlerde araştırma. Ankara: PegemA. 
Balc1, A. \& Bozkurt, S. (2013). Job expectations of generation X and Y teachers in Turkey. World Applied Sciences Journal, 21(4), 599-614.

Baş, M. (2017). Farklı ülkelerde okul özerkliği uygulamalarının değerlendirilmesi: Türkiye'de uygulanabilirliği. Mustafa Kemal Üniversitesi Sosyal Bilimler Dergisi, 38(14), 147-169.

Bowles, S. \& Gintis, H. (1993). Agency, incentives, and democratic accountability. S. Bowles, H. Gintis \& B. Gustafsson (Ed.), Markets and democracy: Participation, accountability and efficiency içinde (s. 11-34). USA: Cambridge University Press.

Butcher, D. \& Clarke, M. (2002). The cornerstone for organizational democracy. Organizational Dynamics, 31(1), 35-46.

Büyüköztürk, Ş. (2007). Sosyal bilimler için veri analizi el kitabı. Ankara: Pegem A.

Büyüköztürk, Ş., Kılıç-Çakmak, E., Akgün, Ö. E., Karadeniz, Ş. \& Demirel, F. (2008). Bilimsel araştırma yöntemleri. Ankara: PegemA.

Byrne, B. M. (2011). Structural equation modeling with AMOS basic concepts, applications, and programming (Multivariate applications series). New York: Routledge.

Cheney, G. (1995). Democracy in the workplace: Theory and practice from the perspective of communication. Journal of Applied Communication, 23(3), 167-200.

Clarke, M. \& Butcher, D. (2006). Reconciling hierarchy and democracy: The value of management learning. Management Learning, 37(3), 313-333.

Colton, J. S., Edenfield, A. C. \& Holmes, S. (2019). Workplace democracy and the problem of equality. Technical Communication, 66(1), 53-67.

Cropanzano, R. \& Molina, A. (2015). Organizational justice. J. D. Wright (Ed.), International encyclopedia of the social \& behavioral sciences (2. b., c. 17) içinde (s. 379-384). Oxford: Elsevier.

Çokluk, Ö., Şekercioğlu, G. \& Büyüköztürk, Ş. (2012). Sosyal bilimler için çok değişkenli istatistik SPSS ve LISREL uygulamaları. Ankara: PegemA.

Davis, L. E. (1967). The design of jobs. Journals of Industral Relations, 9(2), 119-139.

Dewey, J. (2010). Okul ve toplum. Ankara: PegemA.

Diener, R. B. (2011). Positive psychology as social change. London: Springer Dordrecht Heidelberg.

Duverger, M. (1993). Siyasi rejimler. Ankara: Remzi Yayınevi.

Ejder, Y. (1996). Hukuk sözlü̈̆̈̈̈. Ankara: Yetkin Yayınevi.

Ekşi, M. \& Maya, K. (2011). Okul merkezli yönetim sistemine ilişkin öğretmen görüşleri. M.Ü. Atatürk Eğitim Fakültesi Eğitim Bilimleri Dergisi, 33, 45-60.

Erkuş, A. \& Selvi, H. (2019). Ölçek uyarlama ve "norm" geliştirme. Ankara: PegemA. 
Erkuş, A., Sünbül, Ö., Ömür-Sünbül, S., Yormaz, S. \& Aşiret, S. (2017). Psikolojide ölçme ve ölçek geliştirme II. Ankara: PegemA.

Eurydice. (2014). Avrupa'da okul özerkliği: Politikalar ve önlemler. http://sgb.meb.gov.tr/eurydice/kitaplar/ Avrupada Okul Ozerkligi/Avrupada Okul Ozerkligi.pdf sayfasından erişilmiştir.

Forcadell, F. J. (2005). Democracy, cooperation and business success: The case of mondragón corporación cooperativa. Journal of Business Ethics, 56(3), 255-274.

Geçkil, T. \& Tikici, M. (2015). Örgütsel demokrasi ölçeği geliştirme çalışması. Amme İdaresi Dergisi, $48(4), 41-78$.

Geçkil, T. \& Tikici, M. (2016). Hospital employees' organizational democracy perceptions and its effects on organizational citizenship behaviors. Asian Pacific Journal of Health Sciences, 3(2), 123-136.

Gomułka, S. (2017). The global economy in the 21st century: Will the trends of the 20th century continue? Central European Economic Journal, 2(49), $62-72$.

Gözübüyük, A. Ş. (2003). Anayasa hukuku. Ankara: Turhan Yayınevi.

Harrison, S. J. \& Freeman, R. E. (2004). Special topic: Democracy in and around organizations. Academy of Management Executive, 18(3), 49-53.

Heywood, A. (2007). Siyaset. Ankara: Adres Yayınevi.

Hollyer, J. R., Rosendorff, B. P. \& Vreeland, J. R. (2011). Democracy and transparency. The Journal of Politics, 73(4), 1191-1205.

Hooper, D., Coughlan, J. \& Mullen, M. R. (2008). Structural equation modelling: Guidelines for determining model fit. Electronic Journal of Business Research Methods, 6(1), 53-60.

Hoşgörür, V. \& Arslan, İ. (2014). Okul örgütünün finansal kaynaklarının yönetimi sorunu (Yatağan ilçesi örneği). Trakya Üniversitesi Eğitim Fakültesi Dergisi, 4(1), 91-102.

Hu, L. T. \& Bentler, P. M. (1999). Cutoff criteria for fit indexes in covariance structure analysis: Conventional criteria versus new alternatives. Structural Equation Modeling: A Multidisciplinary Journal, 6(1), 1-55.

Jöreskog, K. G. \& Sörbom, D. (1993). LISREL 8: Structural equation modeling with the SIMPLIS command language. Mooresville USA: Scientific Software International.

Karasar, N. (2005). Bilimsel araştırma yöntemi. Ankara: Nobel Yayıncılık.

Kerr, A. (2004). The limits of organizational democracy. Academy of Management Executive, 18(3), 81-97.

King, D. \& Griffin, M. (2019). Nonprofits as schools for democracy: The justifications for organizational democracy within nonprofit organizations. Nonprofit and Voluntary Sector Quarterly, 48(5), 910930. 
Koçak, S. \& Kavak, Y. (2014). Milli Eğitim Bakanlığı'nın öğretmen atama esasları ve kaynak yükseköğretim programları ile ilgili gelişmeler. Hacettepe Üniversitesi Eğitim Fakültesi Dergisi, 29(4), 157-170.

Koçel, T. (2003). İşletme yöneticiliği. İstanbul: Beta Yayım.

Levin, H. M. (1981). Education and organizational democracy. USA: Institue for Research and Educational Finans and Governance Stanford University.

McGregor, N. L. (2005). The contribution of workplace democracy to organizational change. (Doctoral Dissertation). https://www.proquest.com/docview/305394747?pqorigsite=gscholar\&fromopen view=true sayfasından erişilmiştir.

Messner, M. (2009). The limits of accountability. Accounting, Organizations and Society, 34(8), 918-938.

Morrison, K. A. (2008). Democratic classrooms: Promises and challenges of student voice and choice. Educational Horizons, 87(1), 50-60.

Mulgan, R. (2000). Accountability: An ever-expanding concept? Public Administration, 78(3), 555-573.

Müller-Jentsch, W. (1995). Industrial democracy. International Journal of Political Economy, 25(3), 50-60.

O'Brien, L. M. (2005). Social foundations of education and democracy: Teacher education for the development of democratically-oriented teachers. Educational Foundations, 19(3-4), 33-44.

Özdemir, M. \& Bozkurt, S. (2015). Eğitim ve okul yöneticilerinin yeni-kamu işletmeciliği anlayışına ilişkin görüşlerinin incelenmesi. Marmara Üniversitesi Atatürk Ĕ̆itim Fakültesi Ĕ̆itim Bilimleri Dergisi, 42, 317-334.

Perry, L. B. (2009). Conceptualizing education policy in democratic societies. Educational Policy, 23(3), 423-450.

Porta, D. D. (2005). Globalizations and democracy. Democratization, 12(5), 668-685.

Rawls, J. (1993). Distributive justice. New York: Oxford University Press.

Rawls, J. (2017). Bir adalet teorisi. Ankara: Phoenix Yayınları.

Rousseau, J. J. (2012). Toplum sözleşmesi. İstanbul: Türkiye İş Bankası Kültür Yayınları.

Smith, M. (1976). Barries to organizational democracy in public administration. Administration $\mathcal{E}$ Society, 8(3), 275-317.

Stebbins, R. A. (2001). Exploratory research in the social science. Thousand Oaks, CA: Sage.

Şencan, H. (2005). Güvenirlik ve geçerlik. Ankara: Seçkin.

Şişman, M. \& Turan S. (2003). Eğitimde yerelleşme ve demokratikleşme çabaları. Kuram ve Uygulamada Ĕ̆itim Yönetimi, 34, 300-315.

Tabachnick, B. G. \& Fidell, L. S. (2017). Using multivariate statistics. Boston: Pearson. 
Tavşancıl, E. (2005). Tutumların ölçülmesi ve SPSS ile veri analizi. Ankara: Nobel Yayıncılık.

Unterrainer, C., Palgi, M., Weber, W. G., Iwonowa, A. \& Oesterreich, R. (2011). Structurally anchored organizational democracy: Does it reach the employee? Journal of Personnel Psychology, 10(3), 118-132.

Verdorfer, A. P., Weber, W. G., Unterrainer, C. \& Seyr, S. (2013). The relationship between organizational democracy and socio moral climate: Exploring effects of the ethical context in organizations. Economic and Industrial Democracy, 34(3), 423-449.

Warren, M. E. (2014). Accountability and democracy. M. Bovens, R. E. Goodin \& T. Shillemans (Ed.), The Oxford handbook of public accountability içinde (s. 39-54). UK: Oxford University Press.

Weare, C. (2002). The internet and democracy: The causal links between technology and politics. International Journal of Public Administration, 25(5), 659-691.

Weber, W. G., Unterrainer, C. \& Schmid, B. E. (2009). The influence of organizational democracy on employees' socio-moral climate and prosocial behavioral orientations. Journal of Organizational Behavior, 30(8), 1127-1149.

Witteloostuijn, V. A. \& Jong G. (2007). Organizational democracy. S. R. Clegg \& J. R. Bailey (Ed.), International encyclopedia of organization studies (c. 3) içinde (s. 1039-1042). London: Sage Publishers.

Yazdani, N. (2010). Organizational democracy and organization structure link: role of strategic leadership \& environmental uncertainty. Business Review, 5(2), 51-73.

\section{Extended Summary}

The definition of the democracy concept emerges as a political management paradigm, and its possible indicators have been a subject of philosophy, social, and management sciences in all societies where people live in groups. Democracy has been defined as "government of people, by people" and "government based on the sovereignty of people" with the combination of Greek-based "demos" (people) and "kratos" (strength) words (Duverger, 1993; Ejder, 1996; Gözübüyük, 2003; Heywood, 2007). Democracy concept containing concepts such as equality, participation, justice, and popular sovereignty in its foundation, has been criticized from time to time based on the idea that the "government of people by people" cannot be precisely possible (Duverger, 1993; Rousseau, 2012).

Although studies regarding the indicators of both political and organizational democracy have been conducted, no consensus has been reached on how both concepts could be measured as different variables are affecting these two concepts. Geçkil and Tikici (2015) have developed an organizational democracy scale to evaluate the organizational democracy perceptions of the employees working in organizations producing commercial goods. However, no study has been found on the general aspect 
of organizational democracy in schools. Therefore, this study aims to develop a valid and reliable Organizational Democracy Scale according to the perceptions of teachers working at school.

Two participant groups were used in this study. The sample group determined in the pilot practice consisted of a total of 378 teachers working in the National Education Directorate of Çankırı and voluntarily participating in the research. The cluster sampling method was used to represent the different school types in sample selection. The number of teachers working in pre-school, primary, secondary, and high school in Çankırı was listed as a cluster, and the teachers to be sampled were selected randomly from each cluster. 19 (5\%) of the teachers participating in the pilot practice of the research work in pre-school education, $116(30.7 \%)$ in primary schools, $86(22.8 \%)$ in secondary schools, and 157 (41.5\%) in high schools. The second stage participant group consisted of an online survey prepared and 348 teachers working in different cities and participating in the research voluntarily. $19(6 \%)$ of the teachers participating in the second stage of the study work in pre-school education, 116 (33\%) in primary school, 65 (19\%) in secondary school, and 148 (42\%) in high school.

Firstly, the literature was reviewed, and a general theoretical framework on organizational democracy in schools was drawn with the object of measuring the organizational democracy perception in schools to develop a valid and reliable scale. Besides, teachers working in schools were interviewed about their perception of organizational democracy in schools. Considering the institutional framework drawn and the opinions of teachers working in the field, an item pool of 41 was created. The item pool was sent to a total of 15 academics, who are experts in the subject area, including a language specialist, to evaluate the items in terms of meaning, scope, clarity, and openness. At the end of the screening carried out by the subject area experts, four items were removed from the pool because they measured the same goal or were not related to the concept of organizational democracy. The prepared draft scale of 37 items was reviewed by the teachers working in 10 fields in terms of meaning, and no semantic shifts in the draft scale were found. The filling time of the scale was observed to be a maximum of 10 minutes. The prepared 37-item draft scale in the instruction in this direction was finalized and made ready for the pilot practice. The Organizational Democracy Scale was prepared on a 5-point Likert-type scale: "1-I strongly disagree", "2-I disagree", "3-I agree moderately", “4-I agree”, “5-I strongly agree”.

Both data set were examined before the analysis of the data collected within the scope of the study. Descriptive statistics and scatter diagrams were examined to evaluate whether the collected data for the pilot practice of the study is suitable for normal distribution. The mean of the data obtained from the pilot practice was 3.93, the median was 3.94, the coefficient of skewness was -.70 , and the coefficient of kurtosis was 1.35. Since the mean and median were close, and kurtosis and skewness values were in the range of \pm 2 , the data was close to the normal distribution. The data was 
close to the normal distribution in the scatter diagram examined as well. Kaiser-Meyer-Olkin (KMO) and Bartlett's Test of Sphericity were conducted to determine whether the sample size of the pilot practice was suitable for factor analysis. The KMO value of the data obtained from the pilot practice was calculated as .97 . On the other hand, Bartlett's Test of Sphericity was statistically significant $(\chi 2=14329.757, \mathrm{p}<.001)$.

KMO value used in determining the suitability of the sample size for factor analysis is excellent as it approaches 1 , and is unacceptable below 0.50 (Tavşancıl, 2005). Correlation values between scale items were analyzed to examine whether the data obtained from the pilot practice met multiplexed connection assumptions. When the correlation values between the scale items were examined, the highest correlation value appeared to be .81 . The multiplexed connection is asserted to appear in the case of correlation value between items is over .90 in the data set (Şencan, 2005; Tabachnick and Fidell, 2017). As a result of the examination of the pilot practice data, the data were distributed normally, the sample size was suitable for factor analysis, and no multiplexed connection between the items was found.

The collected data was examined in the same way for the second stage of the research. Descriptive statistics and scatter diagrams to determine whether the data was suitable for normal distribution, Kaiser-Meyer-Olkin (KMO) and Bartlett's Test of Sphericity to determine whether the sample size was suitable for factor analysis, and correlation values between scale items to examine whether the data met multiplexed connection assumptions were analyzed. The mean of data obtained in the second stage was 3.70, the median was 3.84, the coefficient of skewness was -.65 , and the coefficient of kurtosis was .15. The KMO value of the data obtained from the second practice was .97, and Bartlett's Test of Sphericity was statistically significant $(\chi 2=12765.624, \mathrm{p}<.001)$. Besides, the correlation value between items was determined .72 as the highest. The data collected for the second stage of the study were distributed normally as well, the sample size was suitable for factor analysis, and the multiplexed connection between the items did not exist.

As a result of the EFA, Organizational Democracy Scale has a three-factor structure with an eigenvalue greater than 1 and all the factors explaining $69.59 \%$ of total variance together. Besides, Cronbach's value on the first factor of the Organizational Democracy Scale is .97, Cronbach Alpha value on the second factor is .95 , and Cronbach Alpha value on the third factor is .84 .

As a result of the CFA, it was observed that the model confirmed the three-factor structure. Fit indexes obtained in the established model are equal, and close to breakpoints show that the structure of the model is confirmed.

The reliability co-efficient Cronbach Alpha is quite high both for the full scale and the subdimensions. Besides, no connection higher than .90 between factors indicates the lack of multiplexed 
connections in the developed measuring tool. Moreover, differentiation between teachers taking place in the groups whose teacher perception is low and high is statistically significant for the whole of the organizational democracy scale. Thus, the distinctiveness power of the scale was found to be high.

The draft scale was created based primarily on literature review and teacher views and was served to expert opinion in this study, focusing on developing a valid and reliable measurement scale to measure the organizational democracy in schools according to teacher views. The pilot practice was performed in the direction of the finalized scale; explanatory factor analysis was made to show the construct validity of the scale with the obtained data. At the end of the explanatory factor analysis, an item with a low factor load value was removed from the scale, and the scale was applied to a different sample group for the main application. Confirmatory factor analysis was performed to verify the model established with the data obtained from the main application. At the end of the analysis, the structure of the model was confirmed since fit indexes of the model established were equal and close to breakpoints. Cronbach Alpha correlation coefficient was calculated to determine the reliability of the scale; the calculated coefficient was found to be high. Finally, differentiation was examined between the two groups consisting of $27 \%$ to determine the item distinctiveness of the scale, and differentiation was found to be significant. As a result, a valid and reliable measurement tool has been developed to measure the level of organizational democracy in schools, considering the opinions of teachers. The scale consists of 36 items in three dimensions: equality and justice, accountability, and participation.

\section{Araştırmacıların Katkı Oranı Beyanı}

$\mathrm{Bu}$ araştırmanın planlanması, yürütülmesi ve yazılı hale getirilmesinde sadece tek bir araştırmacı yer almıştır.

\section{Destek ve Teşekkür Beyanı}

Bu araştırmada herhangi bir kurum, kuruluş ya da kişiden destek alınmamıştır.

\section{Çatışma Beyanı}

Araştırmacının araştırma ile ilgili diğer kişi ve kurumlarla herhangi bir kişisel ve finansal çıkar çatışması yoktur.

\section{Etik Kurul Beyanı}

Bu çalışma, Çankırı Karatekin Üniversitesi Etik Kurulunun 14.7.2020 tarih ve 266 sayılı onayı ile yürütülmüştür. 